$$
\begin{array}{cccc}
\text { S sciendo } & \text { International Conference KNOWLEDGE-BASED ORGANIZATION } \\
\text { Vol. XXV } & \text { No } 2 & 2019
\end{array}
$$

\title{
SHORT PROFILES OF DIFFERENT EUROPEAN INVESTIGATION ORDER DOMESTIC REGULATIONS IN THE EUROPEAN UNION
}

\author{
Georgia PAPUCHAROVA \\ "Neofit Rilski" South-West University, Blagoevgrad, Bulgaria \\ georgia_p@abv.bg
}

\begin{abstract}
The regulatory fragmentation and the excessive administrative formalities in the area of international legal assistance in investigation have created the need for a unitary mechanism. This article is focused on the relatively new instrument for international judicial cooperation in criminal matters - The European Investigation Order (EIO). Specifically, it examines the reflection of Directive 2014/41/EU in several Member States of the EU and provides an overview of the separate national systems. The analysis contained in this paper seeks to identify the issuing, the receiving and the executing authorities in each of the considered countries. Main aspects of the EIO's regulation such as, for an example, its form and content, its transmission, proportionality assessment, deadlines and refusal grounds are seen from the perspective of different national legislations. Although the present study is not intended to be exhaustive, it could clarify to some extent whether an "one-size-fits all" solution in the area of evidence -gathering is an appropriate approach. Special attention is paid to the protection of the right to defence provided by the examined domestic regulations concerning the EIO.
\end{abstract}

Keywords: EIO, mutual recognition of judicial decisions, national legislation, evidencegathering, EIO domestic regulation

\section{Introduction}

Evidence gathering in the European Union is currently governed by Directive 2014/41/EU of the European Parliament and of the Council of $3^{\text {rd }}$ April 2014 regarding the European Investigation Order in criminal matters(The EIO Directive). The principle of mutual recognition isreferred toas a cornerstone of the judicial cooperation in criminal matters since the Tampere European Council of 15 and 16 October 1999 [1]. Although criminal legislations across the EU are different, the mutual trust between countries allows mutual recognition of judicial decisions from one Member State to another. The EIO Directive now proposes that this principle should apply in the area of crossborder evidence gathering. The main priority of the European Investigation Order as a modern legal instrument for judicial cooperation is to create a comprehensive mechanism for obtaining evidence by the Member States "while respecting the state's sovereignty, national security and fundamental rights and freedoms of citizens"'[2]. In this context, another fundamental principle is that free movement of evidence in the EU should be based on"the presumption of compliance with EU law and protecting fundamental human rights"[3].

The new system aims to speed up the process of evidence gathering and to reduce the administrative formalities. The EIO Directive makes the necessary steps forward to achieving this objective by the introduction of a uniform standard form for 
issuing an EIO, which may be transferred by direct contact between the competent authorities. The establishment of strict time limits for recognizing and executing an EIO is another guarantee for faster procedure of obtaining criminal evidence - the competent authority must recognize the EIO no later than 30 days after receiving it and carry out the requested investigative measures no later than 90 days after the date of recognition. The new legal instrument covers the entire process of investigation-from the freezing of evidence to their final transfer in the issuing state. EIO may be issued for the purpose of carrying out all kinds of investigative measures except for setting up a joint investigation team. There is no doubt that this mechanism for judicial cooperation faces important legal challenges in the area of protecting human rights and especially the right of defence and fair trial of persons involved in criminal proceedings. This article analyses the domestic legislations of four Member States differing with regard to the form of their political organization in order to clarify if the implementation of a single European mechanism for obtaining evidence incorporated in different legal systems is an adequate method for improving judicial cooperation in criminal matters between the EU Member States.

\section{Bulgaria}

The Republic of Bulgaria didn't manage to transpose the EIO Directive by $22^{\text {nd }}$ May 2017. The European Investigation Order Act came into force on $20^{\text {th }}$ February 2018.

A European Investigation Order in the Republic of Bulgaria shall be issued by: the relevant prosecutor-in the pre-trial proceeding; the relevant court-in the trial proceeding. An accused person, a defendant or a defense counsel authorized thereby for the implementation of the requisite defence in a criminal proceeding in accordance with the Bulgarian Criminal Procedure Code may request issuing an EIO by the competent authorities under the Bulgarian domestic legislation on the EIO. The issuing procedure shall be started only after a necessity and proportionality assessment has been made by the issuing authorities. Taking into account the rights of the accused person or the defendant is also obligatory in the process of creating such legal instrument.

The power of recognizing and executing an EIO is possessed by the following authorities: in a pre-trial proceeding-a prosecutor of the relevant district prosecution office ormilitary district prosecution office; in a trial proceeding-the relevant district court or militarycourt. The recognition of the order is possible if the conduct it relates to constitutes an offence in accordance with the Bulgarian legislation or if it is included in the list of the offences in Article 10, which are an exception to the double criminality rule because of their seriousness [3].

The competent authorities may refuse to recognize or execute an EIO under the conditions of Article 16 of The European Investigation Order Act. Execution is not possible if:

- there is an immunity or a privilege under Bulgarian legislation;

- it would threaten the national security of the State;

- it would contravene the principle of "ne bis in idem";

- the issuance of the Order is related to proceedings brought by administrative authorities or by judicial authorities for acts for which carrying out investigative measures is inapplicable under Bulgarian legislation in an identical case;

- the request for legal assistance relates to an act, which has been committed outside the territory of the issuing State, has been committed wholly or partially on the territory of the Republic of Bulgaria, and does not constitute a criminal offence according to Bulgarian Legislation;

- it would be incompatible with the respect for the rights andfreedoms guaranteed by the international 
agreements on human rights and fundamental freedoms.

Article 26, paragraph 3 provides for refusal grounds in addition to those set out above. They may be relied on by the competent authority in case of requested temporary transfer of a person held in custody in Bulgaria for the purpose of evidence gathering. Carrying out of such investigative measure is not possible without the explicit consent of the person in custody or if that would cause prolonging of the detention period.

Bulgarian domestic legislation on the EIO involves the possibility for the competent authority to recourse to another less coercive investigative measure if it would be able to achieve the same result.

A legal guarantee for the proper exercise of the right of defence and the right to fair trial is included in the text of Article 18, paragraph 1, which states that: "The legal remedies and time limits available in similar cases underBulgarian legislation shall apply to defense of the persons concerned when carrying out aninvestigative measure and other procedural measures indicated in the European InvestigationOrder." This relates to the Bulgarian Criminal Procedure Code (CPC). For an example, under the conditions of Article 121, Paragraph (2) $\mathrm{CPC}$, a witness has the right to consult a lawyer if he/she is of the view that his/her rights under Article 121, Paragraph (1) are threatened.

\section{Germany}

National provisions transposing Directive 2014/41 can be found in Section 91a-91j of the Act on International Cooperation in Criminal Matters (IRG) supported by the German Directive of the Federal Ministry of Justice and Consumer Protection for International Co-operation in Criminal Matters (RiVASt) [5]. International legal assistance in Germany is built upon a main principle, incorporated in Article 32, paragraph 1 of the German Constitution:
"Relations with foreign states shall be conducted by the Federation (...)" Nevertheless, according to Section 74 paragraph 2 of IRG and in compliance with the agreement of exercise of jurisdiction (Zuständigkeitsvereinbarung) of $28^{\text {th }}$ April 2004 between the German federal and state governments, the federal government confers - with certain exceptions - its power to decide on international legal assistance issues to the state governments. State governments, for their part, confer their power to the German public prosecutor's offices and to the courts.

Authorities competent to issue a European Investigation Order in Germany are all judicial authorities, particularly the Prosecutor General of the Federal Court of Justice, the chief public prosecutor's offices, the prosecutor's offices; the central body; all criminal courts and managing authorities, which are responsible for prosecuting and punishing offences (administrative offences).

For requests which are sent by the German managing authorities, a validation process by a public prosecutor or by a court is provided in Section 91j paragraph 2-4 IRG. Nonetheless, a request of the German fiscal authority (within the scope of Section 386 paragraph 2 of the German Tax Code) does not require validation by a public prosecutor or by a court.

The competent receiving and executing authorities are the same as the issuing authorities referred to above.

German domestic legislation on the EIO complies with the principle of proportionality and this is particularly evident from the constitutional status of it. Article 30, paragraph 3 of The German Constitution states that: "Every action by the state must comply with the principle of proportionality, meaning that every encroachment on the fundamental rights shall be in proportionate balance to the gravity of infringement and degree of suspicion." 
Number 25 paragraph 1, sentence 3 RiVASt also stresses the importance of this principle: "Other Member States might be requested for legal assistance, provided that this is permitted under an international treaty (contractual legal assistance) or under the domestic legislation of the Member State concerned (non-contractual legal assistance). Additional regulations might be agreed at regional level. The principle of proportionality is to be considered."

German domestic regulation on the EIO is provided with strict requirements for its admissibility and recognition and they could be separated into two groups- Special mandatory requirements for the admissibility of an EIO and general grounds for non-recognition of an EIO.

The first category is included in Section 91b of the IRG, namely:

- An EIO is inadmissible if the applying of the investigative measure is limited to offences explicitly determined and punishable by a certain threshold because of their seriousness and the offence covered by the EIO is not included in this list. For an example, Section 100a of the German Code for Criminal Procedures concerning the interception of telecommunication and the offences listed in subsection (2);

- An EIO shall be admitted insofar as the right to refuse to answer certain questions during interrogation and the right to refuse to testify pursuant to Sections 52, 53 and 55 of the German Criminal Procedures Code (GCPC) are not infringed;

- An EIO is inadmissible if objective reasons lead to the conclusion that there is a risk of a violation of the fundamental human rights and freedoms;

- An EIO is inadmissible if the requirement to use the form prescribed by the Directive is not fulfilled;

The general refusal grounds are determined in Section 91e, which includes considerations of:

- national security;
- the rule "ne bis in idem";

- the so called territorial clause;

- the presence of criminalization under the German law of the offence concerned in the EIO;

- the lack of consent of a person held in custody with regard to temporary transfer of this person for the purpose of carrying out an investigative measure;

- failure to reach an agreement for the conditions under which officers would act undercover or with a false identity in Germany.

In addition, if a court responsible for rendering legal assistance is of the view that the requirements for that have not been met it shall motivate its opinion and request a decision by the "Oberlandesgericht".

In case the EIO has been recognized, the execution of the requested investigative measures has to comply with the same provisions as stated for them in the national legislation. For example the requirement of a judge decision for certain investigative measures.

The Directive doesn't aim to circumvent the obligation to respect the fundamental rights and legal principles as enshrined in Article 6 of TEU, including the right of defence and any obligations incumbent on judicial authorities shall remain unaffected. This refers to the opportunity of the suspected or of a lawyer on his behalf to request the issuing of an EIO and also to the national provisions of the GCPC. For an example: Section 136: the right of the accused to be aware of the offence he is charged and of the applicable criminal law provisions and also the right to respond to the charges or to remain silent and Section 166: the right of the accused to make applications to obtain evidence.

Judicial review of admissibility of mutual legal assistance is provided in the German Criminal Procedures Code as an additional remedy against the execution act, for instance: 
- Section 98 paragraph 2: Court decision with respect to an order for seizure;

- Section 101: Court decision with respect to covert measures;

- Section 304: appeal against an issued search and seizure order of a court.

\section{The United Kingdom}

Although judicial cooperation in criminal matters between the UK and the Member States is facing an unclear future because of UK's withdrawal from the EU, the existing legal instruments including the EIO will continue to be used at least until the full completion of this process. The British regulations on the EIO are included in Criminal Law No. 730/2017 - The Criminal Justice (European Investigation Order), made of $31^{\text {st }}$ July 2017. The law contains a lot of legal definitions, clarifying different notions as they are interpreted in England, Wales, Northern Ireland and Scotland or the way they should be understood within the meaning and for the purposes of the EIO regulations. For an example, in Part 1, Regulation 2 "General Interpretation", paragraph 2: “

For the purpose of these Regulations, the central authority -

(a) in relation to England and Wales and Northern Ireland, is the Secretary of State;

(b) in relation to Scotland, is the Lord Advocate;"

The authorities competent to issue an EIO in the UK are judicial authorities and designated public prosecutors according to the legal definitions in the law. The power of the judicial authority to issue an EIO arises only after receiving an application made by a prosecuting authority or by the explicitly referred to in Criminal Law No. $730 / 2017$ police authority with the consent of the relevant prosecuting authority and in any case of pending proceedings, by or on behalf of a party to those proceedings. This application shall persuade the judicial authority that an offence has been committed or that there are reasonable grounds that give rise to a suspicion of such offence, or it shall indicate that proceedings in respect of the offence have been instituted or that an investigation is in progress. A designated prosecutor may issue an EIOif the same conditions are fulfilled. There is an exception to the rule of direct contact between the competent authorities. In case a judicial authority acts as an issuing one, it shall give the EIO to the relevant national requesting authority for transmission to the executing State. Whoever issued an EIO shall respect the principle of proportionality, make sure that the requested investigative measure could be legally exercised under the same conditions in a similar national situation and ensure that all specific provisions related to the requested measures have been fully met. The designated prosecutor (for England, Wales and Northern Ireland) also has the power to validate an EIO at the request of an investigating authority but only under the same conditions for issuing one. Competent to receive an EIO in the UK are the central authorities as defined above for the different parts of the country. In case that the designated central authority recognizes an EIO it shall refer it to the competent executing authorities in order to carry out the requested investigative measures. It is interesting to note, that the central authority (for England, Wales and Northern Ireland) may not make a referral to the executing authorities, if it considers that the offence, which the EIO relates to, has the elements of a serious or complex fraud.

Regulation 28 includes the reasons for nonrecognition and refusal of an EIO in the UK. Furthermore, Schedule 4 of the national regulation sets out the general grounds for refusal that are valid in all circumstances. They are based on certain fundamental principles in the criminal procedural law. There is a specific focus on the protection of human rights. The list of the general grounds for refusal includes:

- Non-breaching an immunity or privilege in accordance with the relevant domestic legislation; 
- Preserving the right to freedom of the expression in the different media types.

- Protecting essential national security interests;

- "Similar domestic case" rule;

- "Ne bis in idem";

- Territorial rule;

- Double criminality rule;

- Compliance with the fundamental rights and freedoms;

- Non-discrimination.

Different refusal options are also provided having regard to the nature of the requested investigative measures (temporary transfer of UK prisoner). Such a provision is a fundamental procedural guarantee for protecting the right of defence of the concerned persons.

\section{Portugal}

Law 88/2017 of 21 August establishes the legal regime for issuing, transmission, recognition and execution of an EIO in Portugal. Article 2, Paragraph 2 states that the new instrument for legal assistance between Member States shall be implemented in the national legal system on the basis of the principle of mutual recognition.

National issuing authorities in Portugal are those "with jurisdiction for conducting the case in the phase in which it is", namely the public prosecutor, the examining judge, the judge, an administrative authority when it comes to an administrative offence proceeding. In the latter case, responsible for validating the EIO is the public prosecutor's office. A specific regulation related to the power of issuing an EIO is that it may also be issued by the national member of the EUROJUST. Issuing an EIO is also possible at the initiative of the procedural subjects. The principle of proportionality shall be respected during the procedure of issuing an EIO.

Receiving and executing authorities according to Law 88/2017 are those having the power to order an investigative measure in a similar domestic case under the Portuguese legislation.

Article 10 of the Law provides for the existence of a central authority - The Public Prosecutor's Office, which is responsible for assisting the issuing, receiving and executing authorities in performing their duties.

The grounds for non-recognition and nonexecution of an EIO are similar to those, incorporated in the other Member State's national legal systems related to above and are subject to the general principles and rules of "ne bis in idem", double criminality, protecting the national security, etc.

There are also similar additional refusal grounds related to the type of the requested investigative measures, as well as an option for recourse to another less coercive investigative measure, which serve as solid basis for the effective exercise of the fundamental rights and the right of defence.

\section{Conclusion}

The consequences of bringing the EIO into use by the Member States are still uncertain. This new legal instrument for judicial cooperation is too recent and cannot yet be fully evaluated. There is no doubt, that the process of adapting all national legal systems to this new regulation requires some additional time. The experience gained from applying the EIO throughout the time would enable the making of an objective assessment of the impact and the effectiveness of this new mechanism. What is certain, however, is that transposing the EIO Directive is a huge step forward for all the participating EU Countries to achieving new dimensions of mutual legal assistance in criminal matters. In this context, it is particularly important to point out that the EIO will serve as a basis for the future creating of a platform for handling electronic evidence [7]. When dealing with electronic evidence the need for additional and specific methods is more than tangible in order to preserve their authenticity and integrity [8]. The 
establishing of a regulation on gathering and using e-evidence "seeks to adapt cooperation mechanisms to the digital age, giving the judiciary and law enforcement tools to address the way criminals communicate today and to counter modern forms of criminality"[9].

\section{References}

[1] The European Council dedicated a special meeting in Tampere, Finland, in October 1999, to the establishment of an Area of Freedom, Security and Justice. During this meeting political guidelines, including in the field of immigration, police and justice cooperation and fight against crime, were elaborated.

[2] Voinova R., Modern Instruments for Evidence-Gathering in Criminal Matters Across EU,International Scientific Conference KBO ,Vol. XXIV, No. 2, pp. 248-254, 2018.

[3] Ralli E.,ThePrinciple of Mutual Recognition Based on Mutual Trust and the Respect for Fundamental Rights: The Case of the Framework Decision on the European Arrest Warrant, European Law Institute, Annual Conference and General Assembly, 2017.

[4] The same 32 categories of offences also set out in the Council Framework Decision 2002/584/JHA of $13^{\text {th }}$ June 2002 on the European Arrest Warrant.

[5] Gesetzüber die international Rechtshilfe in Strafsachen-The part that regulates the EIO is implemented by Law 4 amending the Act on International Cooperation in Criminal Matters.

[6] Richtlinien für den Verkehr mit dem Ausland in strafrechtlichen Angelegenheiten, December 23, 2016

[7] Complete preliminary impact assessment of the European Investigation Order Act Draft, Republic of Bulgaria - Ministry of Justice, September, 2017. - One of the reasons for the transposition of the EIO Directive in the Bulgarian legislation is that applying the EIO is the only way for the state to be part of the future regulation on the exchange of electronic evidence.

[8] Chankova D. and Yurukov V., Electronic evidence-a challenge in evidencing in criminal proceedings, Sofia University, International scientific conference on the modern challenges in criminal proceedings devoted to the $50^{\text {th }}$ anniversary of the entry into force of the Criminal Procedure Code of 1968, Sofia, Bulgaria, pp. 189-200, 2018.

[9] Chankova D. and Voynova R., Towards New European Regulation for Handling Electronic Evidence, US-China Law Review, Vol.15, No. 3, pp. 121-129,2018. 